Jurnal Mandala Pharmacon Indonesia, Vol 5.No.2 Desember 2019

Avaiable online at www.jurnal-pharmaconmw.com/jmpi

p-ISSN : 2442-6032

$e$-ISSN : 2598-9979

\title{
Efek Antidiabetes Kombinasi Ekstrak Kulit Bawang Dayak Dan Kulit Bawang Merah Pada Mencit Yang Diinduksi Aloksan
}

Nikeherpianti Lolok, Haidir Rahmat, Putri Mega Wijayanti

Program Studi Farmasi, STIKES Mandala Waluya, Kendari

\begin{abstract}
ABSTRAK
Ancaman penyakit Diabetes Mellitus ditengah kehidupan masyarakat menjadi momok yang sangat menakutkan karena hampir setiap 10 detik di dunia orang meninggal akibat komplikasi dari penyakit tersebut. Berbagai macam terapi pengobatan untuk diabetes melitus sudah dirancang oleh WHO maupun pemerintah Indonesia baik dari terapi dengan penggunaan obat sintetik sampai ke pengobatan yang berbahan dasar herbal. Pengobatan herbal sebagai terapi diabetes secara empiris sudah dilakukan sejak dulu, salah satunya pada tumbuhan umbi bawang merah dan umbi

menjadi 5 kelompok, kelompok 1 untuk uji kontrol negative (Suspensi NaCMC), kelompok 2 untuk kontrol positif (insulin pen), kelompok 3 untuk control diabetes (diberi pakan), kelompok 4 untuk kombinasi ekstrak.Hasil uji diabetes terhadap mencit yang diinduksikan aloksan menunjukan bahwa kombinasi ekstrak limbah kulit bawang dayak dan ekstrak limbah kulit bawang merah secara signifikan mampu menurunkan kadar gula darah dibandingkan dengan kelompok diabetes, namun hasilnya tidak berbeda nyata dengan kelompok kontrol positif.
\end{abstract} bawang dayak untuk mengevaluasi efek antidiabetes dan hasilnya memberikan efek yang signifikan terhadap penurunan kadar guladarah penderita diabetes tipe 2. Tujuan penelitian ini adalah untuk mengetahui efektifitas kombinasi ekstrak limbah kulit bawang dayak dan limbah kulit bawang merah terhadap penurunan gula darah pada mencit yang diinduksikan aloksan. Pengujian efek antidiabetes hewan uji dibagi
Kata Kunci: Limbah kulit bawang dayak, limbah kulit bawang merah, diabetes mellitus, aloksan

\section{Penulis Korespondensi :}

Nikeherpianti Lolok

Program Studi Farmasi, STIKES Mandala Waluya, Kendari

E-mail : nikeherpianti.apt@gmail.com

\section{PENDAHULUAN}

Ancaman penyakit Diabetes Melitus ditengah kehidupan masyarakat menjadi momok yang sangat menakutkan karena hampir setiap 10 detik di dunia orang meninggal akibat komplikasi dari penyakit tersebut. Setiap hari penderita diabetes 
mellitus semakin bertambah khususnya untuk penderita diabetes mellitus tipe 2 karena kebiasaan buruk dari pola hidup masyarakat. Tiap 19 menit ada satu orang di dunia yang terkena stroke, ada satu orang yang buta dan ada satu orang didunia yang diamputasi akibat komplikasi diabetes mellitus yang awal mulanya disebabkan oleh kenaikan kadar gula darah yang semakin tinggi (WHO, 2015).

Diabetes Mellitus (DM) merupakan penyakit kronik yang terjadi ketika tubuh tidak bisa memproduksi insulin yang cukup atau ketika tubuh tidak menggunakan insulin secara efektif yang berakibat penyakit metabolik dengan karakteristik hiperglikemia kronis serta kelainan metabolisme karbohidrat, protein dan lemak (WHO,2015). Diabetes Melitus (DM) merupakan salah satu masalah kesehatan yang besar, data dari studi global menunjukan bahwa jumlah penderita Diabetes Melitus pada tahun 2016 telah mencapai 420 juta orang. Jika tidak ada tindakan yang dilakukan, jumlah ini diperkirakan akan meningkat menjadi 552 juta pada tahun 2030 (IDF, 2016).

Berbagai macam terapi pengobatan untuk diabetes mellitus sudah dirancang oleh WHO maupun pemerintah Indonesia baik dari terapi dengan penggunaan obat sintetik sampai ke pengobatan yang berbahan dasar herbal. Pengobatan herbal sebagai terapi diabetes secara empiris sudah dilakukan sejak dulu, salah satunya pada tumbuhan umbi bawang merah dan umbi bawang dayak untuk mengevaluasi efek antidiabetes dan hasilnya memberikan efek yang signifikan terhadap penurunan kadar gula darah penderita diabetes. Hasil penelitian yang dilakukan Hidayat dan Zahroh (2017), juga mengemukakan bahwa bawang merah mempengaruhi penurunan kadar gula darah pada penderita diabetes mellitus.

Namun untuk kulit dari bawang merah dan bawang dayak sering kali terbuang percuma dan menjadi limbah, sedangkan menurut penelitian Hidayat dan Zahroh (2017), kulit bawang merah maupun kulit bawang dayak mempunyai kandungan kimia flavonoid yang berpotensi untuk pengobatan diabetes melitus. Kulit bawang merah mempunyai efek terhadap penurunan kadar gula darah. Dari hal tersebut maka peneliti, mengambil sampel limbah kulit bawang dayak dan limbah kulit bawang merah untuk dikombinasi dan dibandingkan efektifitasnya terhadap pemberian insulin.

Berdasarkan latar belakang tersebut, peneliti ingin mengetahui efektivitas dari kombinasi ekstrak kulit bawang dayak dan kulit bawang merah jika dibandingkan dengan potensi hipoglikemik dari insulin eksogen pada mencit jantan dengan 
metode induksi aloksan. Hasil penelitian ini dapat menjadi suatu penemuan obat baru untuk mengatasi penyakit diabetes mellitus

\section{METODE PENELITIAN}

Penelitian ini merupakan penelitian eksperimental laboratorium yang bertujuan untuk mengetahui efek antidiabetes kombinasi ekstrak limbah kulit bawang dayak (Eletherine palmifolia) dan limbah kulit bawang merah (Allium сера) pada mencit yang diinduksi aloksan serta mengetahui efek hipoglikemik jika dibandingkan dengan pemberian insulin eksogen.

\section{A. Alat Penelitian}

Alat-alat yang digunakan adalah seperangkat alat ekstraksi, rotary evaporator, corong, timbangan analitik, penangas air, kertas saring, gelas kimia, gelas ukur, handscone, masker, pipet tetes, jarum oral mencit, mortir dan stamper, kandang hewan coba, botol minuman yang disambung pipet, wadah tempat makanan, kertas HVS, ATK, tinta printer dan seperangkat alat untuk uji kadar gula darah.

\section{B. Bahan penelitian}

Bahan-bahan yang digunakan dalam penelitian ini adalah kulit bawang dayak (Eletherine palmifolia), kulit bawang merah (Allium cepa), etanol 96\%, akuades, pakan hewan coba (mencit), Na.CMC, serta insulin eksogen (insulin pen).

\section{Prosedur Kerja}

1.Pengambilan Sampel

Sampel kulit bawang dayak (Eletherine palmifolia) dan kulit bawang merah (Allium cepa) diperoleh dari Kecamatan Unaaha, Kabupaten Konawe, Sulawesi Tenggara.

2. Pengolahan Sampel

Sampel kulit bawang dayak (Eletherine palmifolia) dan kulit bawang merah (Allium cepa) dipisahkan dari umbinya kemudian dicuci dan dikeringkan. Sampel dikeringkan dengan cara diangin-anginkan selama 2-3 hari, setelah kering sampel diserbukkan.

3. Ekstraksi

Serbuk kulit bawang dayak (Eletherine palmifolia) dan kulit bawang merah (Allium cepa) yang telah diserbukkan masing-masing diekstraksi dengan metode maserasi menggunakan cairan penyari etanol $96 \%$ dengan perbandingan sampel dan cairan penyari 1:4. Proses maserasi ini dilakukan selama 5 hari sambil sesekali diaduk. Masingmasing ampas kemudian di remaserasi kembali sampai diperoleh pelarut bening. Masing-masing hasil penyarian disatukan, lalu diuapkan dengan rotary evaporator, pada suhu $50^{\circ} \mathrm{C}$ hingga didapatkan ekstrak 
kental yang bebas dari pelarut (Doughari, 2012).

\section{Pengkondisian Hewan Coba}

Hewan coba yang digunakan pada penelitian ini yaitu mencit jantan galur Wistar yang berusia 8 minggu dengan berat badan antara 25-30 gr dan hewan coba ditempatkan dalam kandang terpisah sesuai kelompok uji. Hewan coba ini akan diadaptasikan dalam kandang percobaan satu minggu sebelum dilakukan perlakuan. Hewan coba diberi pakan pellet diet standar dan air minum adlibitum (Sornalakshmi dkk.,2016).

5. Induksi Diabetes Pada Hewan Coba

Pada hari pertama sebelum perlakuan semua mencit dipuasakan, kemudian diperiksa kadar gula darah puasanya. Induksi diabetes pada hewan coba ini dilakukan dengan pemberian aloksan monohidrat (150mg/kgBB) secara intraperitoneal. Kadar gula darah mencit diperiksa kembali pada hari kedua, 24 jam setelah penyuntikan aloksan .Mencit dinyatakan diabetes jika memiliki kadar glukosa darah 200-260 $\mathrm{mg} / 100 \mathrm{ml}$ (Sornalakshmi dkk.,2016).

\section{Pengujian Efek Antidiabetes}

Pada pengujian ini hewan uji dibagi menjadi 4 kelompok dimana tiap kelompok terdiri dari 5 ekor mencit.

Kelompok I :Kontrol negatif (Suspensi $\mathrm{NaCMC})$
Kelompok II : Kontrol positif (Insulin pen (Novomix) dengan jenis long acting insulin )

Kelompok III :Kontrol diabetes (Diberi pakan)

Kelompok IV :Kombinasi ekstrak bawang dayak dan kulit bawang merah $(800 \mathrm{mg} / \mathrm{kgBB}$ dan $200 \mathrm{mg} / \mathrm{kgBB}$ per oral)

Setelah 60 menit pemberian sediaan, masing-masing kelompok mencit diberikan glukosa dosis 2 gr/kg BB. Kadar gula darah pada semua kelompok mencit kemudian diperiksa pada menit ke o, 30, 6o, 90, 120 (Sornalakshmi dkk., 2016). Semua sampel darah diambil melalui pemotongan ujung ekor mencit dan kadar gula darahnya diukur dengan glucometer.

Setelah itu, hewan uji diberikan perlakuan sesuai dengan kelompoknya masing-masing. Pada hari ke-3 semua kelompok perlakuan diukur kembali kadar gula darahnya. Perlakuan kemudian diteruskan sampai hari ke-15. Pada hari ke15, dilakukan pengukuran kadar gula darah pada menit ke-o, 30, 60, 90 dan 120.

\section{Pengumpulan dan Pengelolaan}

\section{Data}

Hasil penelitian dinyatakan dalam rata-rata \pm SEM. Signifikansi data dianalisis dengan One-way Analysis of Variance (ANOVA) (program SPSS16.o) dengan post hoc LSD's test. Data dianggap signifikan jika nilai $\mathrm{p}$ kurang dari 0,05 


\section{HASIL DAN PEMBAHASAN}

Grafik hasil pengukuran kadar gula dalam darah mencit (Mus muscullus) pada $\mathrm{H}+3$ dapat dilihat pada gambar berikut :

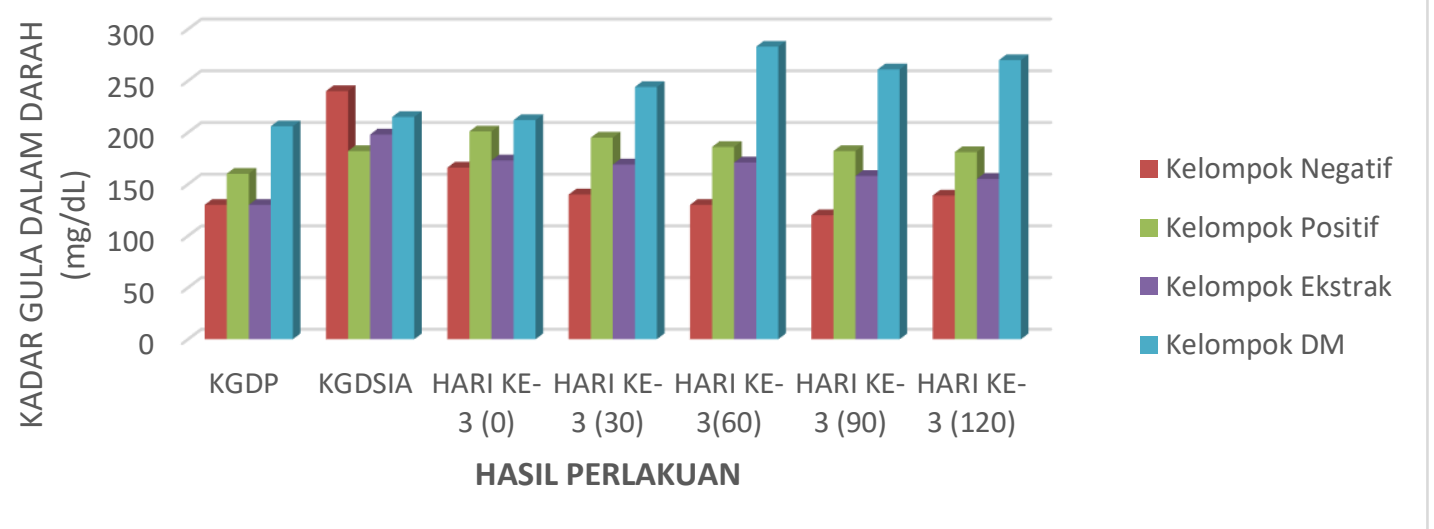

Gambar 1. Hasil Pengukuran Kadar Gula Darah Tikus Putih pada H+3

Ket : $\quad$ KGDP : Kadar Gula Darah Puasa (mg/dL)

KGDA : Kadar Gula Darah 24 jam Setelah Induksi Aloksan $(\mathrm{mg} / \mathrm{dL})$

$\mathrm{H}+3(\mathrm{o})$ : Kadar Gula Darah $\mathrm{H}+3$ Perlakuan jam ke- o (mg/dL)

$\mathrm{H}+3$ (30) : Kadar Gula Darah $\mathrm{H}+3$ Perlakuan jam ke- 30 (mg/dL)

$\mathrm{H}+3(60)$ : Kadar Gula Darah $\mathrm{H}+3$ Perlakuan jam ke- 60 (mg/dL)

$\mathrm{H}+3$ (90) : Kadar Gula Darah $\mathrm{H}+3$ Perlakuan jam ke- 90 (mg/dL)

$\mathrm{H}+3(120)$ : Kadar Gula Darah $\mathrm{H}+3$ Perlakuan jam ke- $120(\mathrm{mg} / \mathrm{dL})$

Grafik hasil pengukuran kadar gula dalam darah mencit (Mus muscullus) pada $\mathrm{H}+15$ dapat dilihat pada gambar berikut :
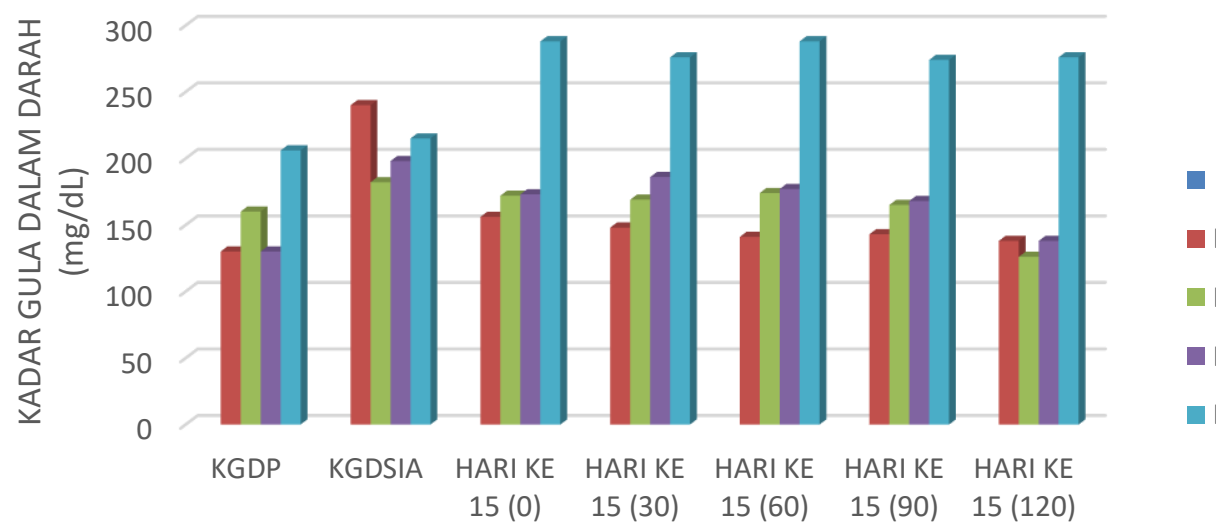

Kelompok Negatif

Kelompok Positif

- Kelompok Ekstrak

Kelompok DM

HASIL PERLAKUAN

\section{Gambar 2. Hasil Pengukuran Kadar Gula Darah Tikus Putih pada H+15}

Ket : $\quad$ KGDP $\quad$ Kadar Gula Darah Puasa (mg/dL)

KGDA : Kadar Gula Darah 24 jam Setelah Induksi Aloksan (mg/dL)

$\mathrm{H}+15(\mathrm{o}) \quad$ : Kadar Gula Darah H+15 Perlakuan jam ke- o (mg/dL)

$\mathrm{H}+15(30) \quad$ : Kadar Gula Darah $\mathrm{H}+15$ Perlakuan jam ke- 30 (mg/dL)

$\mathrm{H}+15(60)$ : Kadar Gula Darah H+15 Perlakuan jam ke- 6o (mg/dL)

$\mathrm{H}+15$ (90) : Kadar Gula Darah $\mathrm{H}+15$ Perlakuan jam ke- 90 (mg/dL)

$\mathrm{H}+15(120) \quad$ : Kadar Gula Darah H+15 Perlakuan jam ke- 120 (mg/dL) 
Diabetes mellitus merupakan suatu penyakit yang dapat meningkat jika dipicu oleh beberapa factor seperti kegemukan (obesitas), kurang aktivitas, penduduk berumur diatas 40 tahun meningkat, berkurangnya penyakit infeksi dan kekurangan gizi (Soegondo, 2015).

Senyawa dalam limbah kulit bawang dayak dan limbah kulit bawang merah yang dapat menurunkan kadar glukosa darah yaitu senyawa flavonoid. Aktivitas antioksidan yang terdapat pada senyawa flavonoid dapat menangkap atau menetralkan radikal bebas, sehingga dapat memperbaiki keadaan jaringan yang rusak. Flavonoid dapat berperan dalam kerusakan jaringan pankreas yang diakibatkan oleh alkilasi DNA akibat induksi aloksan sebagai akibatnya dapat memperbaiki morfologi pankreas. Flavonoid dilaporkan memiliki aktivitas antidiabetes yang mampu meregenerasi sel pada pulau Langerhans (Prameswari, 2014).

Sebelum dilakukan perlakuan, hewan coba yaitu mencit diadaptasikan terlebih dahulu dengan lingkungan selama 7 hari untuk menghindari terjadinya stres pada saat perlakuan. Sebelum perlakuan dimulai, mencit dipuasakan terlebih dahulu selama 16 jam agar terjadi pengosongan lambung oleh makanan yang dapat mempengaruhi hasil penelitian, tetapi tetap diberi minum.
Pada pengujian diabetes melitus, 20 ekor mencit dibagi menjadi 4 kelompok perlakuan. Masing-masing kelompok terdiri dari 5 ekor mencit yaitu kelompok negatif yang diberikan suspensi $\mathrm{NaCMC}$, kelompok positif yang diberikan insulin pen, kelompok kombinasi ekstrak limbah kulit bawang dayak dan limbah kulit bawang merah serta kelompok diabetes mellitus yang hanya diberikan pakan. Perlakuan tersebut diberikan selama 15 hari dan diukur kadar gula darah mencit pada hari ke 3 dan hari ke 15. Akan tetapi terlebih dahulu diukur kadar gula darah puasa dan kadar gula darah setelah induksi aloksan. Pengukuran kadar gula darah mencit tersebut menggunakan alat glukometer.

Berdasarkan hasil analisis statistik menunjukkan bahwa kadar gula darah sebelum induksi diabetes dan sesudah induksi diabetes diperoleh hasil yang berbeda nyata tiap kelompoknya yaitu $\mathrm{p}$ $<0,05$. Selanjutnya diberi perlakuan hingga $\mathrm{H}+15$ kemudian diukur kembali kadar gula darah pada mencit. Pada penelitian ini data-data yang terkumpul dianalisis menggunakan program SPSS for windows. Tahap pertama dilakukan uji Normalitas menggunakan metode Kolmogorov-Smirnov terhadap data kadar gula darah. Jika hasil uji menunjukan distribusi data adalah normal yang masing-masing hasil uji ditunjukan oleh nilai $p$ (sig) > 0,05. Kemudian dilanjutkan dengan uji one 
way ANOVA memberikan nilai $p$ (sig) < $o$,o5artinyaada efek penurunan kadar gula darah terhadap pemberian kombinasi ekstrak limbah kulit bawang dayak dan limbah kulit bawang merah, kemudian dilakukan analisis Uji Post Hoc apabila dari hasil uji one way ANOVA diketahui adanya perbedaan signifikan, maka dilanjutkan uji Post Hoc yaitu untuk mengetahui perbedaaan bermakna pada masing-masing kelompok.

Data kadar gula darah sesudah perlakuan diolah menggunakan metode Uji Kolmogorov-Smirnov untuk menentukan distribusi data. Hasil pengolahan data menunjukkan bahwa data terdistribusi normal sehingga pengolahan data dilanjutkan menggunakan analisis varians satu arah (One Way ANOVA) untuk menentukan perbedaan antar kelompok perlakuan.

Analisis menggunakan variansi satu arah menunjukkan pada $\mathrm{H}+3$ perlakuan menit ke- 0, 30, 60, 90 dan 120 dengan nilai signifikansinya yaitu $p<0,05$. Untuk $\mathrm{H}+15$ perlakuan menit ke- o, 30, 60, 90 dan 120 dengan nilai signifikansi juga didapatkan bahwa $\mathrm{p}<0,05$ yang menunjukkan adanya perbedaan bermakna pada kadar gula dalam darah mencit (Mus muscullus). Setelah diperoleh adanya perbedaan yang bermakna pada kadar gula dalam darah mencit (Mus muscullus) maka uji statistik dilanjutkan dengan uji Post Hoc untuk mengetahui antar kelompok mana yang terdapat perbedaan bermakna kadar gula darah.

Dalam penelitian tersebut, berdasarkan hasil analisis statistik pada $\mathrm{H}+3$ perlakuan menit ke- o, 30, 60, 90 dan 120 diperoleh hasil yaitu terdapat perbedaan yang bermakna $(p<0,05)$ antara kelompok kontrol positif dan kombinasi ekstrak dibandingkan kelompok kontrol negatif dengan nilai signifikan $(p<0,05)$. Tidak ada perbedaan yang bermakna antara kelompok kontrol positif dan kombinasi ekstrak dengan nilai signifikan ( $p>0,05)$. Selanjutnya hasil analisis statistik pada $\mathrm{H}+15$ perlakuan menit ke- o, 30, 60, 90 dan 120 juga menunjukkan adanya perbedaan bermakna pada kelompok kombinasi ekstrak dan kelompok kontrol positif dibandingkan dengan kelompok kontrol negatif dengan nilai signifikan masingmasing yaitu $(p<0,05) . K a d a r$ gula darah kelompok perlakuan mengalami penurunan setelah diberikan kombinasi ekstrak, sedangkan hasil analisis pada kelompok kontrol positif dibandingkan kombinasi ekstrak menunjukkan tidak ada perbedaan yang bermakna baik pada menit ke- o, 30, 60, 90 dan 120 nilai signifikan $(\mathrm{p}<0,05)$.

Berdasarkan hal penelitian diatas, sejalan dengan beberapa penelitian lainnya dimana dikatakan bahwa senyawa yang terkandung dalam kulit bawang dayak dan kulit bawang merah mempunyai khasiat sebagai antidiabetes. 
Senyawa-senyawa yang terkandung dalam kulit bawang dayak yaitu senyawa flavonoid, saponin, polifenol, alkaloid, steroid, fenolik, tanin, triterpenoid dan kuinon (Sulastri, dkk., 2015).Adapun senyawa-senyawa yang terkandung dalam kulit bawang merah yaitu alkaloid, flavonoid, saponin, tannin, antrakuinon dan triterpenoid (Rahayu dkk. 2015).

Data dari uji One Way ANOVA analisis menggunakan variansi satu arah menunjukkan pada $\mathrm{H}+3$ perlakuan menit ke- o, 30, 60, 90 dan 120 dengan nilai signifikansi $(p<0,05)$ dan untuk $\mathrm{H}+15$ perlakuan menit ke- o, 30, 60, 90 dan 120 dengan nilai signifikansi juga menunjukkan $(p<0,05)$. Data yang diperoleh menunjukkan bahwa $\mathrm{H}_{\mathrm{o}}$ ditolak, artinya terdapat perbedaan bermakna dari uji kadar gula darah mencit (Mus muscullus). Hasil uji Post Hoc pengukuran kadar gula darahmenunjukkan bahwa perbedaan bermakna terdapat pada kontrol positif dan kelompok kombinasi ekstrak dibandingkan kelompok kontrol negatif.

\section{KESIMPULAN}

Berdasarkan uraian hasil penelitian diatas maka dapat disimpulkan bahwa kombinasi ekstrak limbah kulit bawang dayak dan limbah kulit bawang merah dapat menurunkan kadar gula darah pada mencit (Mus muscullus) yang diinduksi aloksan.

\section{UCAPAN TERIMA KASIH}

Dengan selesainya penelitian ini, penulis mengucapkan terima kasih kepada semua pihak yang telah berkontribusi yaitu Kemenristekdikti yang telah memberikan dana kepada peneliti, Dr. PH. Hj. Tasnim, S.KM., M.PH, selaku ketua STIKES Mandala Waluya Kendari , Waode Yuliastri, S.Farm.,M.Si.,Apt selaku selaku Ketua Program Studi Farmasi STIKES Mandala Waluya Kendari, Staf Administrasi STIKES Mandala Waluya Kendari, Laboratorium Farmakognosi-Fitokimia dan Biofarmasi STIKES Mandala Waluya Kendari, mahasiswa(i) Program Studi Farmasi STIKES Mandala Waluya Kendari, serta seluruh pihak yang telah membantu selama penulis melakukan penelitian.

\section{DAFTAR PUSTAKA}

Doughari, J.H. 2012. Phytochemicals: Extraction Methods, Basic Structures and Mode of Actionas Potensial Chemotheraupetic Agents. Phytochemicals_A Global Perspective of the iRole in Nutrition and Health. Intech.

Hidayat, A. Zahro. 2017. Pengaruh Bawang Merah Terhadap Penurunan Kadar Gula Darah Pada Penderita Diabetes Mellitus di Desa Sidoraharjo Kecamatan Kedamean Kabupaten Gresik. Jurnal Fakultas Keperawatan dan kebidanan. Universitas Nahdlatul Ulama Surabaya. 
International Diabetes Federation. 2016.

Diabetes Evidence Demands Real

Action From the Un Summit On Non-

Communicable

Diseases.www.

International Diabetes Federation

(diakses 8 Desember 2016).

Prasmeswari, O. M. dan Widjanarko, S. B. 2014. Uji Efek Ekstrak Daun Pandan Wangi. Jurnal Pangan dan Agroindustri No.2, Vol. 2, FTP Universitas Brawijaya. Malang. Hal. 16 - 27.

Rahayu, S. Kurniasih. N. Amalia.V. 2015. Ekstraksi \& Identifikasi Senyawa Flavonoid dari Limbah Kulit Bawang Merah Sebagai Antioksidan Alami. Alkimiya Vol.2.
Soegondo, dkk. 2015. Penatalaksanaan Diabetes Melitus Terpadu. Jakarta: FKUI.

Sornalakshmi, V. Tresina Soris. P. Paulpriya K. Packia Lincy.M. dan Mohan.V.R. n.d.2016. Oral Glucose Tolerance Test (OGTT) In Normal Control and Glucose Induced Hyperglycemic Rats With Hedyotisle Schenaultiana DC. Group. 1:0-9.

Sulastri, E. Cristadeolia. O. dan Yusriadi. 2015. Formulasi Mikroemulsi Ekstrak Bawang Hutan dan Uji Aktivitas Antioksidan. Jurnal Pharmascience. Vol.2 (2). Hal:2;9

WHO.2015.Diabetes.http://www.who.int/me diacentre/factsheets/f5312/en.

(diakses 24 Januari 2015). 